\title{
Construction of an Industry Cycle Indicator for Profitability Prediction Analysis of Aggregate Firms in Bangladesh
}

\author{
Maria Afreen ${ }^{1}$ \\ $\mathrm{PhD}$ (Financial Economics), Faculty of Economics and Business, University Malaysia Sarawak, Malaysia
}

\begin{abstract}
Keywords: Industrial cycle, Vulnerability, Forecasting, Leading indicator, Profitability, Bangladesh.
\end{abstract}

\section{ABSTRACT}

Purpose of this study: In the aggregate industrial sector, government intervention to influence demand within the economy is generally counterproductive, while the optimal policy is to concentrate on supply-side reforms that help the economy become efficient. The objective of this study was to construct a unique industry cycle indicator for Bangladeshi aggregate firms within this industrial sector. The specific objectives were to assemble a unique industry cycle indicator which recommends early signals of a firm's industrial vulnerability, identify industry cycle indicator turning points and evaluate the predictive performance of the industry. The industry cycle indicator model demonstrates the macroeconomic fluctuations in the industrial sector.

Methodology: The industry cycle indicator was constructed following the approach of the Conference Board (2000). The result wasthen tested for robustness with a macro-stress test. Lagged independent variables were used in this study to allow early predictions by the ICI for the year in which the financial crisis happened.

Main Findings: The industry cycle indicator model underplays the role of aggregate industrial efficiency in influencing the economic cycle. By forecasting directional changes, this leading indicator allows policymakers to be made aware of revolutions in the financial industry and to undertake early precautionary steps to prevent vulnerability. Here, the constructed industry cycle indicator demonstrates a remarkable lead time of around 6 months for predictions and outperforms by the leading against the reference series.

Research Limitations/Implications: The industry cycle indicator model rejects the Keynesian approach and also rejects monetarism. It tends to be associated with neo-classical economics. The ICI generally assumes that shocks to productivity lead to economic fluctuations. In other words, a temporary fall in output is an inevitable consequence of a drop in productivity within the industrial sector. It also leads to adjustments to this new equilibrium and enables resources to discover more productive uses.

Novelty/Originality: This research demonstrates that enhanced knowledge of components of the macro-prudential policy framework combined with the existence of a certain degree of standardisation of the macro-prudential tools and indicators is essential. This can significantly develop the capability of the financial markets supervisory authorities to forecast systemic risk and to avoid or reduce the consequences of industrial crises. The present study reflects a situation for upcoming researchers who intend to study and develop their interests in this area.

\section{INTRODUCTION}

In the context of Bangladesh, the focus was on the national stock exchanges, the Chittagong Stock Exchange (CSE) and the Dhaka Stock Exchange (DSE), which maintain almost identical listing criteria and procedures to cover the financial markets and industrial sectors portfolio, as well as the national aggregate economic overview. These are maintained as virtually dual listings by all listed companies, securities firms and brokers. However, a demutualisation of the stock exchanges has occurred that removed inherent conflicts of interest. As a result, the

\footnotetext{
${ }^{1}$ Corresponding Author: scholar.maria.afreen@gmail.com
} 
exchanges are merging which eliminates opportunities for arbitrage between the exchanges, public trust and liquidity. Listed companies in Bangladesh are also partly responsible for the weak performance of the two stock exchanges because corporate systems, transparency and strong corporate governance are not yet ingrained in the Bangladeshi economy. Supervision and applicable regulations for investment funds, securities firms and the stock exchanges are also inadequate. In addition, the foreign aid flow to Bangladesh may decline due to economic crises, since with low economic growth investors may feel reluctant to invest. However, since most foreign aid to Bangladesh comes through multilateral agencies, this may not be a major problem. Additionally, in meeting its demands for food and non-food items, Bangladesh largely depends on imports (Bangladesh Bank, 2018). Commodity prices including those of edible oils, wheat, fertilizers and rice have decreased substantially in the globalmarket, particularly after the financial crisis. This allows Bangladesh to import from abroad at lower prices.

This combination of vulnerability factors may lead to overall national economic distress, which can in turn result in afinancial market crisiswithin this industry sector, especially in the context of the economic circumstances of banks in Bangladesh. The causes of instability in the financial system create awareness of the necessity to take measures that reduce the potential for financial constraints (Hawkesby, 1998). A number of measures can be undertaken by policymakers to promote financial stability andto maintain a stable macroeconomic environment in response to recent financial crises. Strong corporate governance with a robust infrastructure can maintain a proper degree of supervision over the industrial sector system. Significant additional resources have been providedby international financial agencies with the aim ofunderstanding and identifying the potential leading indicators of financial instability. For example, the World Bank and the IMF began a joint initiative for a pilot Financial Sector Assessment Program in 2010, to better assess financial sector vulnerabilities and to improve risk management practices as part of an international effort (Ministry of Finance Bangladesh, 2015). The interest rate is depicted by the profits earned per Bangladeshi Taka and indicates how efficiently the banks, in representing this industry sector,are able to generate revenues.

In Bangladesh, compared to the previous year (2018), the economy expanded by $8.2 \%$ in 2019 , as measured by the national GDP. The Bangladeshi GDP growth rate (Figure 1) reached anaverage all-time high of 8.2\% in 2019, compared to an average increase of $5.9 \%$ between 1994 and 2019, and a recorded low of 4.08\% in 1994. The Bangladeshi inflation rate in recent fiscal years was $6.4 \%$ in 2015, 6.7\% in 2016 and 6.9\% in 2017. The Bangladeshi economy, despite natural disasters, has continued to register a growth rate of around $6 \%$ despite external shocks and political unrest over the last few years. The areas of foreign investment, exports and remittances may be affected in the case of Bangladesh's economy because this growth rate is likely to be sustained in the present fiscal year in spite of the current financial crisis (Yousfi, 2016). A possible uncertainty involves the extent and timing of any economic effects. As there is rarely an occurrence in the capital markets of Bangladesh, this channel is less likely to place a drain on capital. However, apprehension persists that FDI into the Bangladesh economy may decrease, due to the ongoing world financial crisis, which may affect the economy unfavorably. In Bangladesh, the macroeconomic fundamentals have been consistent for the last few years with a sustainable budget deficit and public debt. In this context, if this crisis affects the Bangladeshi economy, the government may be forced to resort to a fiscal policy of expansion (Ministry of Finance Bangladesh, 2019).

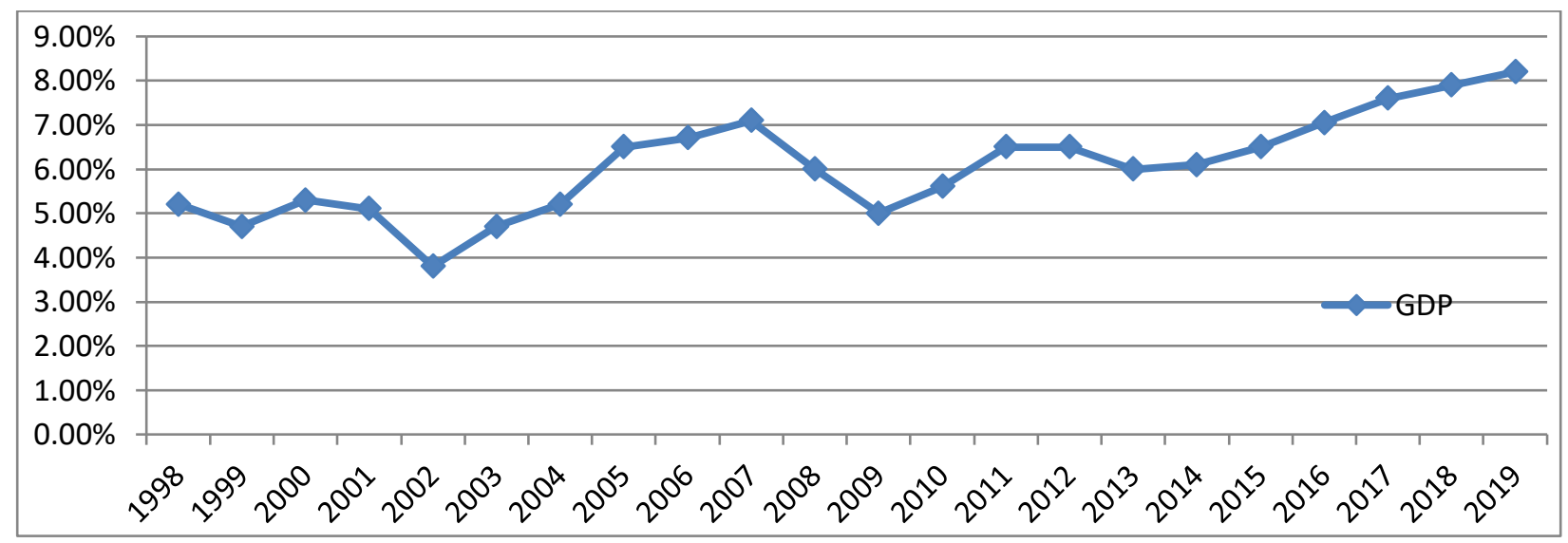

Figure 1: GDP Growth Rate in Percentage Terms (1998-2019) of Bangladesh (Global Economic Prospects, World Bank, 2019). 
In the case of the national industrial market sector, massive support exists for the idea that a focused monetary policy can achieve a credit cycle for an industry arenawhich has its own asset prices and significant implications for systemic stability (Blundell-Wignall \& Roulet, 2014). Unintended consequences may occur which focus on the current monetary ease. Given the practical limitations of specific industries or financial markets, industry firm cycle forecasting policy needs to rely more heavily on existing tools during the current crisis. In order to capture various aspects, this study uses certain categories of indicators of industrial sector instability or vulnerability to distress. The equity-to-assets ratio (capital ratio) represents capital adequacy $(\mathrm{C})$ and it is considered to incorporate the optimum level of financial market capitalization. Net interest margin is symbolized by NIM, which demonstrates the firm's profitability and solvency. Non-performing loan (NPL) is the share of non-performing assets to total assets which demonstrates the proportion of loan loss provisions to total average loans and reserves for loan losses as a share of non-performing assets. Generally, a weaker net interest margin is expected to be completely positively related to bank distress. In both cases, a higher share of loan loss provisions to total average loans, and the comparatively higher share of non-performing assets to total assets, are expected to increase the probability of failure. Meanwhile, as greater coverage for expected losses, higher reserves should correspond to higher expected losses and they could also be proxied.

This research concerns analysis of the fluctuations or deviations of economic trends in the financial factors of the economic vulnerabilities in the Bangladeshi financial markets or industry sector, such as banks, in terms of credit, capital weighted risk, loans, liquidity, expenditure-income ratio and profitability portfolio. Thus, this research forecasts the risk factors and possible preventative measures in that context. An effective legal framework is needed for the central bank, along with necessary powers to improve its supervisory and regulatory capacities, as well asthe streamlining of enforcement of prudential guidelines for the macro-economy. Therefore, it is possible to realise that measurement of the financial economy should be obtained as a precaution for welfare and for improving the economic progress of Bangladeshi firms in the industry sector. The construction of an ICI for Bangladeshi firms will enable the forecasting of any potential economic vulnerability within this industry sector. It will also assist preventive measures to be undertaken to safeguard the Bangladeshi financial markets sector. Therefore, research is required to construct an industry cycle indicator (ICI) for the purpose of protecting the Bangladeshi financial market industry. That is the intention of this study.

\section{LITERATURE REVIEW}

Based on the indicator approach, a study by Voon, Puah \& Wong (2016) conveys noteworthy implications in its analysis of the housing cycle, in the context of Borneo, particularly the East Malaysian component. To account for the extreme limitations of the high-frequency housing-related time series data, their study modeled the housing cycle in the state of Sarawak, the largest state in East Malaysia. Another study by Puah, Kuek, Arip \& Wong (2016) replicated the movements of the property cycle in Malaysia and predicted the movements and substantial changes in the dynamics of the property market. This study revealed that banking performance was significantly affected by the financial crisis in 2008. Saddique, Ahmad, Mumtaz \& Arif (2016) presented a regression analysis that exposed the effect of financial variables on the bank's performance prior to and following the financial crisis.

A paper presented by Lestano, Jacobs \& Kuper (2003) regarding an early warning system for six Asian countries demonstrated that indicators are effective. Their study distinguished between three types of financial crisis (currency crises, banking crises and debt crises) and extracted four groups of indicators from the literature - external, financial, domestic (real and public), and global - that would belikely to reflect the probability of financial crises. Using a panel of $40 \mathrm{EU}$ and OECD countries coveringthe period 1970-2010, Babecky et al. (2011) constructed an early warning system that consisted of a discrete and a continuous model. In the former, an extensive database was collected of various types of economic crisis, called CDEC 40-40, and potential leading indicators were examined. Alessi \& Detken (2011) constructed Quasi Real Time Early Warning Indicators for costly asset price boom and bust cycles.

Previous work by Baker (2018) focused on systemic outcomes as consequences of the implications of a macroprudential policy. These led to collective social expectations, an ontology that formed the basis of the term 'macromoralities', which provides ethical justifications for public forms of systemic stabilization. Dumicic (2017) emphasized in his study the main stages of a macroprudential cycle, the relationship between macroprudential policy and other economic policies, and the costs and benefits of macroprudential regulations. In previous studies on outcome reviews, issues related to the public dissemination of indicators have been outlined, in recognition of their crucial role in the strengthening of financial sector surveillance and the supervision of the global financial system (Evans, Leone, Gill \& Hilbers, 2016). Ghosh et al. (2016) maintained the importance of a macro-prudential policy 
and surmised that while changes in global conditions have an important bearing on crisis susceptibility, countries that allow the buildup of macroeconomic and financial vulnerabilities during boom times, and which receive mostly debt flows, are significantly more experience an end to capital inflow surge episodes oncea financial crisis occurs. Blanchard et al. (2016) demonstrated capital flows from an expansionary or contractionary perspective and elaborated the necessity of macro-prudential policy analysis. Igan \& Tan (2015) correlated the capital inflows, credit growth, and financial systems through analysis, and suggested incorporating the implementation of a benchmark through a macro-prudential policy. Lombardi \& Siklos (2016) constructed an index of macroprudential capacity, which was developed based on the assumption that credit growth and the indicator were strongly inter-related. Bruno \& Shin (2015) suggested the construction of an indicator as a remedy for cross-border banking and global liquidity. Cerutti et al. (2015) documented the use of macroprudential policies for 119 countries over the period 2000-13, covering many instruments. This demonstrated that emerging economies most frequently use macroprudential policies with regard to indicator creation, especially those related to foreign exchange. Jan \& Rongrong (2019) demonstrated in their research that by means of indicator creation, a macroprudential policy can be used to retain financial stability without triggering an economic slowdown, or as a complement of monetary policy to offset the buildup of financial vulnerabilities arising from monetary easing.

In the Bangladeshi context, a number of issues cause economic vulnerabilities, which may consequently create a financial crisis. Based on a cause and effect analysis, the following crisis determinants were identified: asharp reduction in GDP growth; boom-bust cycles of inflation, credit expansion and capital inflows; increasing real interest rates; an increasing incremental capital-output ratio; declining bank deposits; a significant fall in real exchange rates; falling imports; and an adverse terms-of-trade shock. Together, these reasons predetermine the negative consequences existing in the Bangladeshi economy.

The leading indicators could be differentiated from one country to another. Asian distress was followed by increasing foreign liability and credit growth which measured the vulnerability of the corporate sector and industrial firms. A study by the Ministry of Finance Bangladesh (2016) identified the following key results: a continuous sharp reduction in GDP (recession), a drop in the financing of trade, crashes in the stock market, and an increase in real exchange rates. Crisis factors also affected the Bangladeshi industrial sector's well-being. These vulnerability movements played a vital role in the detection of turning points during crisis moments in Bangladesh. Therefore, this study focuseson the construction of preventive measure initiatives, and inaugurates the construction of an ICI as a vital resource for the Bangladeshi economic sector in its recovery from financial distress. This indicator would therefore create safeguards for the Bangladeshi industrial economy.

An effective legal framework is needed for the central bank, best owing it with the necessary powers to effect improvements in its supervisory and regulatory capacity. Streamlining the enforcement of prudential guidelines is also required. Therefore, it should benoted that financial economy measurements must be obtained as a precaution for the purposes of welfare and to improve economic progress within the Bangladeshi industrial economy. The construction of an ICI for the Bangladeshi industrial economy will enable the forecasting of any economic upcoming vulnerability which would affect industrial firms. It would also facilitate the creation of preventive measures that would safeguard the Bangladeshi industrial sector. Therefore, research is required toconstruct an ICI for firms in the Bangladeshi industrial sector, which is the aim of this paper.

\section{METHODOLOGY}

Predictions of turning or deviating points in the financial markets or industrial sector cycle involve several major procedures. First, it was vital to ascertain an appropriate indicator of the economic activity related to the financial markets industry, which was also regarded as the reference series. The selected combinations of the component series were utilized in the construction of an industry cycle indicator (ICI) indicator on the basis of the step-wise indicator construction methodology proposed by the Conference Board (2000). In order to establish an empirically sufficient and sound ICI, the non-parametric index aggregation process was adopted, outlined by the Conference Board (2000), the detailed step by step procedure of which was as follows:

i. Compute the month-to-month changesfor each component, where $\mathrm{i}=1, \ldots, \mathrm{n}$ for a symmetric percentage change formula based on the symmetric percentage change formula below:

$$
r_{i, t}=\frac{X_{i, t}-X_{i, t-1}}{X_{i, t}+X_{i, t-1}} * 200
$$

Note that if the composite involves a series in percentage form, then the simple arithmetic difference will be applied. 
ii. Calculate the standardisation factor by inversing the standard deviation in regard tothe month-to-month changes for each component series and perform an adjustment by multiplying these two factors (standard deviation and component series) to yield the monthly contribution of each component series $\left(C_{i}, \mathrm{t}\right)$.

iii. Across the components, add the adjusted symmetric changes for each month to obtain the sum of the adjusted monthly contribution:

$$
S_{t}=\sum_{i=1}^{n} C_{i, t}
$$

iv. Then, based on the symmetric percentage change formula, derive the preliminary index recursively by letting the initial index value equal 100.

The index value of the subsequent month will be:

$$
I_{2}=\frac{200+S_{2}}{200-S_{1}} * I_{1}
$$

Given the constructed ICI's, transformation into the industry cycle is required, as the present study seeks to examine the Bangladeshi financial markets or industrial sector cycle in a growth cycle setting rather than the classical cycle. The transformation involves the following procedure:

i. Detrending the ICIs to obtain the cyclical components using the CF filter developed by Christiano \& Fitzgerald (2003) and

ii. Smoothing to remove irregular components through a simple centered moving average. Zhang \& Zhuang (2002) proposed this average should cover a period of seven months.

Based on the indicator construction technique implemented in the present study and the industry cycle approach, the cyclical movement ofthe ICI and the reference cycle of NIM were established using the filtering technique created by Christiano \& Fitzgerald (2003). A finite approximate band-pass filter was proposed by $\underline{\text { Christiano \& Fitzgerald }}$ (2003), optimized for each time series. This paper presents its construction on the assumption of this optimal approximation: following a pure economics background analysis, the data was generated from the perspective of the Bangladeshi aggregate firms industry.

This research establishes a chronological reference sequence for the Bangladeshi firms' industry cycle from 1998 to late 2018, against the significant backdrop of the worldwide recession in the late 2000s and the most recent domestic socio-economic developments, which once again emphasise the significance of pinpointing the dates of financial industry cycle turning points. The derivation of the accurate dates of switches between expansions and recessions allows the detection of the point in time at which the Bangladeshi financial markets industrial economy entered the recent recessionary economic cycle regime in the late 2000 s, and the verification of the affirmation that, up to the end of 2015, it had not yet exited the recession. Both the non-parametric and parametric procedures are relied up onto prove coherence among the attained turning points and examine the establishment of a reference chronology by implementing the Bry and Boschan (BB) dating algorithm (Bry \& Boschan, 1971). The Bry and Boschan (1971) methodology is a widely-used non-parametric method for detecting economic activity through key turning points. The algorithm identifies an individual time series from the local minimum and maximum values. In regard to the turning points, the principal advantage of the BB algorithm is its determination of the local minimum and maximum values. Accordingly, previously identified turning points are rarely impacted by the addition of new observations. The Bry-Boschan algorithm was formerly based on monthly data. Harding \& Pagan (2002) developed an algorithm (the BBQ algorithm) for dating periods of recession and expansion on a monthly and a quarterly basis. This was based on data that identified the case of an identical set of different variables of the turning points. The current research makes the particular suggestion that the Bangladesh firms' industrial economy entered the recessionary industry cycle regime in 2008, a state which continued throughout 2012. Furthermore, the paper discusses potential remedies that could predict the well-being of the Bangladeshi industrial economy, and provide precautionary measures in this context.

To conduct directional accuracy testing, the cyclical changes were divided into three trichotomy scenarios: a large predicted increase with no significant changes, a large predicted decrease, and removal of the small predicted changes with a threshold point of $50 \%$ (Greer, 2011). Thus, the directional accuracy rate could be calculated based on the following formula: 
Directional Accuracy Rate $(\mathrm{DAR})=\frac{C_{S}}{N_{S}} x 100$

To conduct binomial testing, the null hypothesis was specified as "the forecasting model is set at $50 \%$ in terms of the probability of a correct prediction of the direction of change". Depending on the outcome of directional accuracy testing (DAR), any rejection of the null hypothesis focused on two significant distinct conclusions. If the DAR weregreater than $50 \%$, then the forecasting model would be independent of wild guesses. On the other hand, if the DAR were below $50 \%$, it would be expected that wild guesses could obtain precise and correct predictions (Greer, 2011).

In this study, net interest margin (NIM) was selected as the reference series. NIM is measured as the difference between the interest paid on the funding of assets and the interest gained from earning assets, or as the spread calculated between the rates earned on loans and the rates which are paid on deposits. These are both primarily driven by central bank monetary policy and external capital market effects. The results indicate that creditfacilitating industrial sectors or bank-specific factors such as the loan-loss provision to total assets, the loan-deposit ratio, operating expenses to total assets and equity capital to total assets are significant factors (Aghaie, 2009). Macroeconomic variables and bank size in the case of revenue show no impact. In determining the profitability of a bank, its internal factors play a significant role. Such factors includeits operational efficiency, liquidity, risk aversion (capital ratio) and credit quality. These factors significantly determine a bank's profits of earnings.

On the other hand, a combination of four variables - non-performing loans, capital asset ratio, cost-income ratio, and non-interest income - was selected as component series with which to construct the industrial cycle indicator. This ICI advances the reference series and detects turning points of economic episodes within Bangladeshi firms' industry cycle. Thus, the ICI helps to guide the government and policymakers to undertake preventive measures for safeguarding purposes in regards to the Bangladeshi industrial economic sector's volatility in moments of contingency.

\section{RESULTS / ANALYSIS}

The cyclical movement of the ICI and NIM is shown in Figure 2, where ICI moves ahead of NIM (the reference series). This reveals the leading trend arising from a prediction approach and through the construction of an indicator. Exceptions could be seen in the first trough and the fourth peak. In the Bangladesh context, according to Table 1, the economic seasonal episodes in accordance with the timeline could be described as follows: food price hikes and investment reduction from 2000 to 2002; a rise in remittance and a drop in capital flow from 2005 to 2007; inflow of remittance and slowdown in growth from 2008 to 2010; improved macro-economic balance and food price hikes, as well as the occurrence of natural disaster, from 2011 to 2012; and structural reforms and achievement of middle-income country status from 2014 to 2018 onwards. In predicting the movement of the firms' industry cycle in Bangladesh with a prominent lead time and reliability as an early signaling tool, the constructed ICI demonstrated a strong capability to functionas a predictor for the financial industry sector economy roadmap in Bangladesh.

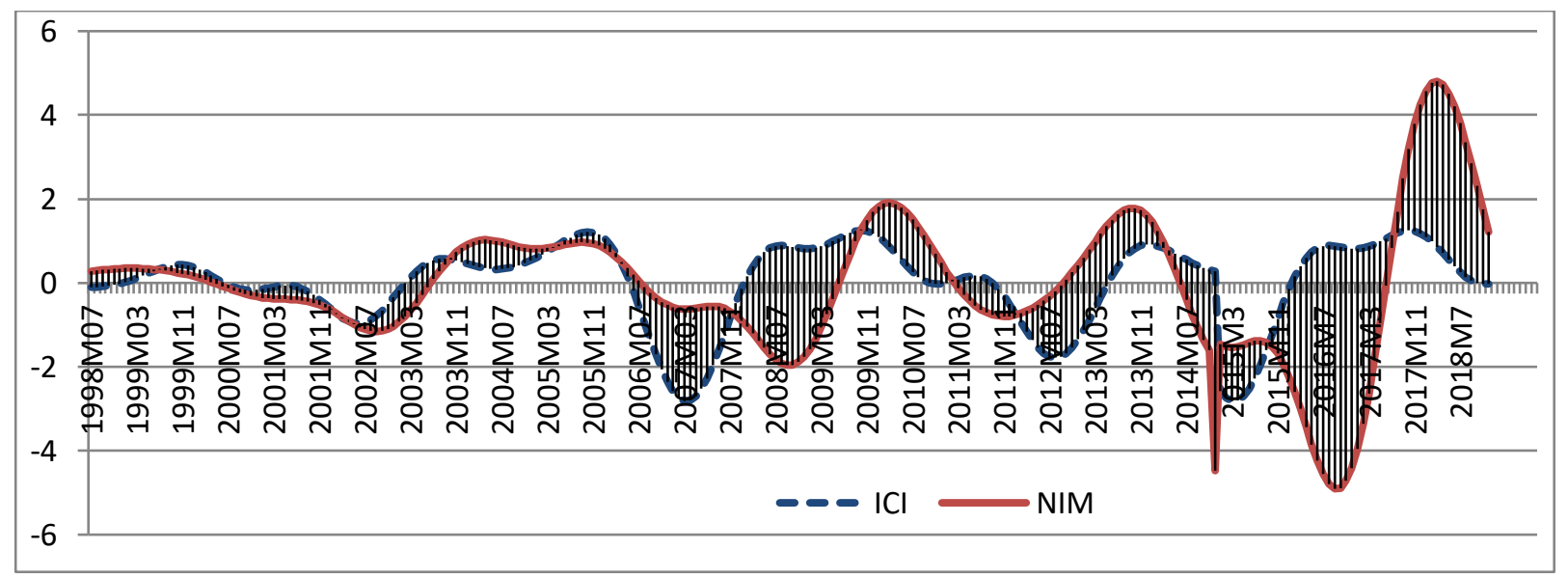

Figure 2: ICI versus NIM (1998-2018) (Source: Constructed by author's data analysis) 
The author proposes that the ICI constructed in this study can trace the general movement of the financial industry sector focusing on financial markets in an absolute manner. In this research, the ICI has demonstrated its capacity to forecast crisis points 6 months earlier than the reference series (NIM). This is demonstrated in the graph in Figure 2.

Table 1:Results of turning points analysis of the ICI and the NIM (1998-2018)

\begin{tabular}{|c|c|c|c|c|}
\hline $\begin{array}{l}\text { Cycle } \\
\text { Condition }\end{array}$ & NIM & ICI & $\begin{array}{l}\text { Difference } \\
\text { (Months) }\end{array}$ & Important Events \\
\hline Peak & 2001M01 & $2000 \mathrm{M} 03$ & 10 & Overall GDP growth increased \\
\hline Trough & 2002M07 & $2002 \mathrm{M} 10$ & (3) & Rise in fuel and food prices \\
\hline Peak & 2006M03 & 2005M09 & 6 & Rise in remittances, Low inflation, GDP increase \\
\hline Trough & 2007M05 & 2006M11 & 6 & Revenue and capital flows lowered, fewer exports \\
\hline Peak & 2008M08 & 2008M01 & 8 & $\begin{array}{l}\text { Liquidity reduced inflation and improved macro-economic } \\
\text { balance }\end{array}$ \\
\hline Trough & 2010M03 & 2009M05 & 10 & Significant slowdown in growth \\
\hline Peak & 2011M05 & 2011M07 & (2) & Agricultural wages and remittance inflows increased \\
\hline Trough & 2012M12 & 2012M06 & 6 & Natural disaster occurred; food price hike \\
\hline Peak & 2014M01 & 2013M03 & 10 & Structural and institutional reforms occurred \\
\hline Trough & $2017 \mathrm{M} 03$ & $2016 \mathrm{M} 10$ & 5 & Arrival to middle-income country status \\
\hline \multicolumn{3}{|c|}{ Total Difference (Months) } & 56 & \\
\hline \multicolumn{3}{|c|}{ Average Prediction (Months) } & 6 & \\
\hline
\end{tabular}

Source: Author's calculation

Based on the directional accuracy and binomial test proposed by Greer (2011), the directional accuracy test results for the constructed ICI for the Bangladeshi industrial financial markets are presented in Table 2. The tabulated results demonstrate that the constructed ICI can predict Bangladesh's major industrial sector cycle turning points with up to $68 \%$ accuracy. Moreover, the binomial test results demanded a rejection of the null hypothesis at the $10 \%$ significance level for the ICI, indicating that the constructed ICI performs better than a wild guess. This suggests that the source of success or correct prediction produced by the ICI is the inherent predictive power of the indicator. Given the strong evidence of the directional accuracy assessment, the robustness of the ICI in forecasting the Bangladeshi financial markets industrial cycle is supported.

Table 2: Results of the Directional Accuracy Test and the Binomial Test

\begin{tabular}{lllllll}
\hline Lag & $\mathbf{1}$ & $\mathbf{2}$ & $\mathbf{3}$ & $\mathbf{4}$ & $\mathbf{5}$ & $\mathbf{6}$ \\
\hline Directional Accuracy Rate (DAR) & $45 \%$ & $51 \%$ & $55 \%$ & $59 \%$ & $61 \%$ & $68 \%$ \\
\hline P(Binomial) & 0.01 & 0.00 & 0.02 & 0.00 & 0.03 & 0.00 \\
\hline
\end{tabular}

\section{DISCUSSION}

The policy implications of this study are that the credit-facilitating industry and financial markets, especially banks, should explore strategies to reduce their lending rates in order to attract deposits through lower operational costs; they should also seek to diversify their sources of deposits. When lending, a borrower's ability to obtain credit decreases with higher interest rates. Policymakers should seek a low rate of inflation by means of an effective application of expansionary and contractionary monetary policy which would promote a lower lending or monetary policy rate (MPR). Moreover, in terms of growth, the results should be executed as this would invariably lead to increased profitability for the commercial banks as well as firms in the industry sector, together with an increase in credit expansion which would have a positive economic impact.

Although credit risks cannot always be avoided, a number of safeguard strategies can control their incidence and minimize a bank's losses. Thus, effective management of credit risk may allow banks not only to avoid unexpected losses from their credit portfolio but also help them to increase their sustainability, safeguard them from forced provisioning, and secure them against capital erosion and declining profitability, among other benefits. Thus, the credit risk management guidelines, credit appraisal format, approval and disbursement process, valuation of collateral and security, early awareness process, monitoring and follow-up processes, due diligence process, documentation checklist, and governance should be well-structured and adapted according to the nature and size of 
the borrower. Rigorous training and motivational programs for the bank's employees, extended use of information technology in the credit management procedure, the establishment of a credit counseling unit or cell for borrowers, organization of talk-shows in the media between borrowers and financial market incorporated bankers may all assist management of credit risks.

\section{CONCLUSION}

Based on this research, an industry cycle indicator (ICI) was proposed which would obtain forecasts of Bangladeshi firms' industry sector welfare. The probable combination of variables might be undertaken as a permutation of a component series including features such as capital asset ratio, inflation, industry production index, non-performing loans, cost-income ratio, non-interest income, stock turnover ratio, reserve of gold and real interest rates. To lead the industry sector measurement of performance efficiency as net interest margin (NIM), in terms of the component series, this research has demonstrated in practical terms that an ICI could be constructed for the successful identification of turning points which would in turn predict the vulnerability of firms within the industry sector of Bangladesh.

In order to identify the major sources of risk, a close examination was conducted of the explanatory power of the useful leading indicators; the analysis was made easier to follow through the division of the indicator (ICI) as leading to the reference series (NIM) introduced in this study. The composition of variables was intended to represent distinct areas from which a risk or a signal of potential crisis could originate, such as the banking system, capital markets, and aggregate firms' industrial sector. The contributions of individual variables as a composition that generated the indicator (ICI) is the outcome of conducting the prediction approach. It follows that regarding the sources of risk, it is beneficial for a macroprudential policy to monitor aggregate industry sector variables and the financial markets arena since they represent economic segments of firms that are important sources of risk.

\section{LIMITATIONS AND FUTURE RECOMMENDATIONS}

Availability of data is a constraint which forms the major limitation of this research. Primary data collection was unable to utilise more genuine sources. From the perspective of secondary data collection, website data sources were expected and considered to be reliable. Public and private sector data sources were collected for the purpose of conducting data analysis, but private sector data collection comprises greater restrictions, as well as privacy issues, in that rigid confidentiality was adhered to. Occasionally bias, manipulation, and bureaucracy persisted when researchers were engaged in the practical aspect of collecting the data, which clearly created obstacles.

In summary, as a minimum, the following factors should be documented and considered in approving credit by the financial markets in terms of the credit-facilitating industry sector: (i) the clearly stated purpose of the credit and the source(s) of repayment; (ii) the current risk profile of the borrower; (iii) the integrity and the reputation of the borrower; (iv) the borrower's repayment history record and their sensitivity to economic and market deterioration; the current capacity to repay, based on historical financial movements analysis and cash flow projections; (v) a forward-looking analysis in terms of their capacity to repay should be conducted based on different scenarios; (vi) the legal status and capability of the borrower to execute documents and meet their liability; (vii) the status of the borrower's probable economic sector and the borrower's expertise, as well as their position within that sector; (viii) the proposed terms and conditions of the credit, comprising credit covenants in case of default; and (ix) the adequacy and enforceability of collateral or guarantees. Finally, it is essential to understand to whom credit is being granted. To elaborate further on risk in the financial sector, the result of lower growth is the principal concern, in the current term, due to the reappearance of political unrest and an upturn in inflation. This may, theoretically, enforce the use of reserves. Further deterioration in the Central Bank's financial health could challenge fiscal sustainability and constrain availability. Therefore, if the focus is narrowed to the financial sector, prior to entering into any new prospective credit relationship, banks should become acquainted with the borrower or the organization that they are dealing with and should ensure that the latter are of sound repute and truly creditworthy.

\section{REFERENCES}

Alessi, L. and Detken, C. (2011). Quasi Real Time Early Warning Indicators for Costly Asset Price Boom/bust Cycles: A Role for Global Liquidity. European Journal of Political Economy, 27(3), 520-533.

https://doi.org/10.1016/j.ejpoleco.2011.01.003

Please cite this article as: Maria, A. (2020). Construction of an Industry Cycle Indicator for Profitability Prediction Analysis of Aggregate Firms in Bangladesh. International Journal of Social Sciences and Economic Review, 2(4), 9-18. doi:doi.org/10.36923/ijsser.v2i4.76 
Aghaie, A. (2009). Using Bayesian Networks for Bankruptcy Prediction: Empirical Evidence from Iranian Companies. International conference on information management and engineering, Malaysia. DOI: $10.2139 /$ ssrn. 2227603

Babecky., Jan, Havranek., T., \&Mateju., J., \& Rusnak., M., \&Smidkova., K., \&Vasicek., B. (2011). Early Warning Indicators of Economic Crises: Evidence from a Panel of 40 Developed Countries. Czech National Bank. Working Paper Series 8. http://ies.fsv.cuni.cz/en/node/372

Bangladesh Bank. (2018). Bangladesh Bank Website. Prudential regulations for banks: Selected issues. Bangladesh Bank Working Paper. htttp: www.bb.org.bd

Blanchard, Olivier, Ostry., J., Ghosh., A., and Chamon, M. (2016). "Capital Flows: Expansionary or Contractionary?" American Economic Review (Papers and Proceedings), 106(5), 565- 569. Series 2018. DOI: 10.1257/aer.p20161012

Bruno, V., and Shin. H. S. (2015). "Cross-Border Banking and Global Liquidity," Review of Economic Studies, Oxford University Press, vol: 82(2), 535-564. DOI: https://doi.org/10.1093/restud/rdu042

Bry, G., \& Boschan, C. (1971). "Cyclical analysis of time series: Selected procedures and computer programs". New York: National Bureau of Economic Research.https:dl.acm.org/doi/book/10.5555/578823

Blundell-Wignall, A., \& Roulet, C. (2014). Macro-prudential Policy, Bank systemic risk and capital controls. OECD Journal: Financial Market Trend, 13(2), 1-22. DOI: 10.1787/fmt-2013-5jzb2rhkhks4

Baker., A. (2018). Macroprudential regimes and the politics of social purpose, Review of International Political Economy, 25:3, 293-316. DOI: 10.1080/09692290.2018.1459780

Conference Board (2000). Business Cycle Indicators Handbook. New York: The Conference Board.

Cerutti. E. M., Claessens., S. and Laeven., L. (2017). “The Use and Effectiveness of Macroprudential Policies: New Evidence," Journal of Financial Stability, 28(March Edition), 203-224..

Christiano, L.J., \& Fitzgerald, T.J. (2003). "The Band Pass Filter". International Economic Review, 44(2), 435-465. DOI: $10.1111 / 1468-2354 . t 01-1-00076$

Dumicic., M. (2017). A Brief Introduction to the World of Macroprudential Policy. Journal of Central Banking Theory and Practice. Vol: 1, pp: 87-109. http: 6. 10.1515/jcbtp-2017-0005.

Gill., M. S., Hilbers., P. L. C., Leone., A. M., Evens., O. (2000). Macroprudential Indicators of Financial System Soundness. International Monetary Fund, IMF Occasional Papers. January Edition. http: www.imf.org

Greer, M. (2011). Combination forecasting for directional accuracy: An application to survey interest rate forecasts. Journal of Applied Statistics, 32(6), 607-615. DOI: 10.1080/02664760500079027

Ghosh, A. R., Ostry,. J. D. and Qureshi., M. S. (2016). "When Do Capital Inflow Surges End in Tears?” American Economic Review Papers \& Proceedings, 106(5), 581-585. DOI: 10.1257/aer.p20161015

Hawkesby, C. (1998). Maintaining financial system stability: the role of macro-prudentialindicators. Reserve Bank of New Zealand, 63(2), 38-52.

Harding, D., \& Pagan, A. (2002). Dissecting the cycle: a methodological investigation. Journal of Monetary Economics, 49(2), 365-381.

Igan. D. O., Tan. Z. (2015). Capital Inflows, Credit Growth, and Financial Systems. IMF Working Paper, WP/15/193 (Washington, DC: International Monetary Fund). http: www.imf.org

Jan., K. \& Rongrong., S. (2019). Macroprudential policy, central banks and financial stability: Evidence from China. Journal of International Money and Finance, Elsevier, vol. 93(C), pages 19-41. DOI: $10.1016 /$ j.jimonfin.2018.12.015

Lestano., Jacobs, J.P.A.M. and Kuper, G.H., (December, 2003). Indicators of Financial Crises Do Work! An EarlyWarning System for Six Asian Countries. CCSO Working Paper 200313, University of Groningen. Available at SSRN: https://ssrn.com/abstract=480021 or http://dx.doi.org/10.2139/ssrn.480021

Lombardi., D., Siklos., P. L. (2016). Benchmarking macroprudential policies: An initial assessment. Journal of Financial Stability. Vol: 27(December), 35-49. https://doi.org/10.1016/j.jfs.2016.08.007

Ministry of Finance Bangladesh (2015). Bangladesh Economic Review. Economic Advisers WingFinance Division, Ministry of Finance, Bangladesh. http: www.mof.org

Ministry of Finance Bangladesh (2016). Bangladesh Economic Review. Economic Advisers Wing Finance Division, Ministry of Finance, Bangladesh. http: www.mof.org

Ministry of Finance Bangladesh (2019). Bangladesh Economic Review. Economic Advisers Wing Finance Division, Ministry of Finance, Bangladesh. http: www.mof.org

Puah, C. H., Kuek, T. H., Arip, A., \& Wong, S. S. L. (2016). Forecasting property market dynamics: Insights from the property cycle indicator. International Information Institute. 9(6B), 2225-2232.

URL: http://ir.unimas.my/id/eprint/13944 
Saddique., A., Ahmad., M., Mumtaz., R., Arif., M. (2016). The Effect of Financial Variables on Bank Performance Pre and Post Financial Crisis. Journal of Finance and Accounting. 4(6), 378. DOI: $10.11648 /$ j.jfa.20160406.18.

Voon, Z. H., Puah, C. H., \& Wong, S. S. L. (2016). Housing marketdynamics: New insights from the indicator approach. Journal of Economics and Economic Education Research, 17(3), 1-8. URL: http://ir.unimas.my/id/eprint/17417

Yousfi, I. (2016). The impact of macroeconomic,structural variables and banks characteristics on Islamic banks performance: Panel evidence from Jordanian banks (2000 - 2014). El-Bahith Review, 16/2016, 29-42.

Zhang, W., \& Zhuang, J. (2002). Leading Indicators of Business Cycles in Malaysia and the Philippines. Asian Development Bank, Economics and Research Department, Working Paper Series 32. URL: www.adb.org.

\section{Author's Bio-Data:}

Maria Afreen: Dr. Maria Afreen Completed her Ph.D. in "Financial Economics" from University Malaysia Sarawak, Malaysia in 2018 with a merit-based scholarship. She has expertise in data analysis in the areas of Volatility Forecasting \& Macro-economic Modeling, Credit Risk Management, Constructing Risk Indicator \& Filtering tools. She has a remarkable number of high impact factor indexed peer-reviewed journal publication records at the international level. 